\title{
Clomiphene Stimulation Test in Men Abusing Anabolic-Androgenic Steroids for Long Time
}

\author{
Medras $\mathbf{M}^{1,2}$, Jozkow $\mathbf{P}^{2^{*}}$, Terpilowski $\mathrm{L}^{3}$ and Zagocka $\mathrm{E}^{4}$ \\ ${ }^{1}$ Department of Endocrinology, Diabetology and Isotope Treatment, Wroclaw Medical University, ul. Pasteura 4, 50-367 Wroclaw, Poland \\ ${ }^{2}$ Department of Sports Medicine, University School of Physical Education, ul, Paderewskiego 35, 51-612 Wroclaw, Poland \\ ${ }^{3}$ Department of Emergency Medical Services, Wroclaw Medical University, ul. Pasteura 4, 50-367 Wroclaw, Poland \\ ${ }^{4}$ Laboratory of Male Infertility, ul. Kosciuszki 108A/18, 50-441 Wroclaw, Poland \\ "Corresponding author: Pawel Jozkow, Department of Sports Medicine, University School of Physical Education, ul. Paderewskiego 35, 51-612 Wroclaw, Poland, Tel: \\ +48 7134733 06; Fax: +48 7134730 53; E-mail: jozkow@gmail.com
}

Received date: February 27, 2014, Accepted date: April 23, 2014, Published date: April 30, 2014

Copyright: ( 2014 Medras M, et al. This is an open-access article distributed under the terms of the Creative Commons Attribution License, which permits unrestricted use, distribution, and reproduction in any medium, provided the original author and source are credited.

\begin{abstract}
Objective: Androgenic-anabolic steroids (AAS) are commonly used by athletes and recreational athletes. In some cases they induce persistent anabolic steroid-induced hypogonadism (ASIH).

Design: In an observational study we assessed the function of the pituitary-gonadal axis in a series of men with suspected ASIH.

Methods: Clomiphene stimulation test (CST) was performed in 13 hypogonadal adult men with previous, prolonged exposure to AAS. We evaluated the response of luteinizing hormone (LH), follicle-stimulating hormone (FSH) and total testosterone ( $\mathrm{T})$ to $50 \mathrm{mg}$ of clomiphene daily administered for a week.

Results: Mean concentrations of hormones before and after clomiphene administration were respectively (mean $\pm \mathrm{SD}$ ): $3 \pm 1.2$ and $8.3 \pm 2 \mathrm{mlU} / \mathrm{ml}$ for $\mathrm{LH} ; 3 \pm 1.1$ and $10 \pm 14.6 \mathrm{mlU} / \mathrm{ml}$ for $\mathrm{FSH}$; and $2.3 \pm 0.6$ and $7.2 \pm 1.7 \mathrm{ng} / \mathrm{ml}$ for $T(p<0.001)$.

Conclusions: Men with ASIH, after a long-time withdrawal of AAS, present an intact reaction of gonadotropins and testosterone to clomiphene stimulation.
\end{abstract}

Keywords: Anabolic agents; Hypogonadism; Clomiphene; Diagnostic tests; Gonadotropins; Testosterone

\section{Introduction}

Illicit use of AAS is widespread in many parts of the world. Recent surveys show that $2.4 \%$ of Australian students report lifetime AAS use [1], while in Sweden between 10000 and 100000 subjects may be exposed to AAS every year [2]. In Poland $6.2 \%$ of young males and $2.9 \%$ of young females admit that they use anabolic agents. Data from other countries and continents suggest that AAS users can be counted in millions [3-5]. The situation is emerging as a public health concern [6].

Side effects of AAS are common and involve diverse body organs and systems [7-9]. One of the most prominent AAS effects is suppression of the hypothalamo-pituitary-gonadal (HPG) axis leading to decreased production of testosterone and spermatozoa. Although the gonadal function usually recovers after withdrawal of AAS, in a growing number of cases there is observed a secondary, functional, often hypogonadotropic, anabolic steroidinduced hypogonadism (ASIH) [10]. Low concentration of testosterone may persist even after several months-long cessations of AAS.
Hypogonadism understood as testosterone deficiency is associated with a broad range of somatic, sexual and psychological symptoms [10-12]. Acquired, hypogonadotropic hypogonadism (AHH) is a consequence of anatomical and functional alterations of the hypothalamus and/or the pituitary. It is found in tumors, infiltrative and vascular disorders of the sellar region. It may be also observed after brain injury, neurosurgery, in the course of anemia, uremia, alcoholism or as a side effect of gonadotropin suppression during endocrinological, psychiatric or urological treatments [13,14]. Data on clinical aspects of ASIH is scarce.

Our aim was to assess the HPG axis with use of the clomiphene stimulation test in adult men with a history of long-term exposure to AAS.

\section{Subjects and Methods}

The study had an observational character. It was performed in thirteen adult men (aged $25 \pm 4$ ), former AAS users, who were referred to an andrological outpatient clinic because of low testosterone concentration. Studied subjects were informed on the aim of the investigation and the diagnostic procedure to which a written consent was given.

Each athlete had a medical interview with a full andrological checkup. None of the studied cases presented disturbances of sexual 
Citation: Medras M, Jozkow P, Terpilowski L, Zagocka E (2014) Clomiphene Stimulation Test in Men Abusing Anabolic-Androgenic Steroids for Long Time. J Steroids Hormon Sci 5: 129. doi:10.4172/2157-7536.1000129

Page 2 of 4

differentiation and maturity or physical symptoms of hypogonadism. They did not suffer from any chronic medical conditions and did not receive medications for at least 3 months prior the investigation.

All of the investigated men had total testosterone (T) concentration $\leq 3.2 \mathrm{ng} / \mathrm{ml}$. Their clinical status was good (normal: body mass index, blood pressure, testicular volume). Four of the studied men fathered children before starting AAS, one - during AAS use.

Our cases derived from the same sport environment and received AAS in a similar manner (3-4 cycles of several weeks duration eg. Deca Durabolin $4000 \mathrm{mg}$, Omnadren $7000 \mathrm{mg}$, Metanabol $1200 \mathrm{mg}$ and/or Oxandrolone $5000 \mathrm{mg}$ during a year). They used AAS for $3.9 \pm 1.6$ years. The drug-free interval before the investigation was $2.1 \pm 1.0$ years.

Laboratory evaluation consisted of fasting measurements of: luteinizing hormone (LH), follicle-stimulating hormone (FSH), total testosterone (T), estradiol (E2), sex-horrmone binding globulin (SHBG), prolactin (PRL), sperm count assessed after 7-days sexual abstinence. In 7 cases magnetic resonance imaging of the pituitary was performed showing intact anatomy of the sellar region.

After confirmation of hypogonadism a week-long test with $50 \mathrm{mg}$ clomiphene citrate/day, (clomiphene stimulation test, CST) was performed $[15,16]$. We compared basal and stimulated concentrations of LH, FSH and T.

Blood samples were obtained from the ulnar vein between 7.00 and $9.00 \mathrm{AM}$. Serum was stored at $-20^{\circ} \mathrm{C}$ until being used in the certified laboratory. Radioimmunoassay kits were used for measurements of $\mathrm{T}$ and E2 (Diagnostic Products Corporation, USA). The intra- and interassay coefficients of variation $(\mathrm{CV})$ were $5.5 \%$ and $5.9 \%$ for $\mathrm{T}$ and $5.8 \%$ and $7.4 \%$ for E2. SHBG, FSH and $\mathrm{LH}$ were measured using immunoradiometric assay-IRMA kits (Immunotech, Czech Republic). The intra- and interassay CV were 3.8 and $7.0 \%$ for SHBG; $5.0 \%$ and $3.8 \%$ for $\mathrm{FSH} ; 6.7 \%$ and $3.7 \%$ for $\mathrm{LH}$.

The statistical analysis was performed using the PQ Stat version 1.4.4.126. Concentrations of hormones in the CST test were assessed with the Wilcoxon signed-rank test. Associations among: age, duration of AAS use, duration from AAS withdrawal and results of the CST test were evaluated with U Mann-Whitney test and Spearman's rank correlation coefficient (fold changes of hormones' concentrations). A p-value less than 0.05 were considered significant.

\section{Results}

The raw results of the clomiphene stimulation test in the investigated men are presented in table (Table 1).

\begin{tabular}{|l|l|l|l|l|l|l|}
\hline S.No & $\begin{array}{l}\text { Age } \\
\text { (years) }\end{array}$ & $\begin{array}{l}\text { Length of } \\
\text { AAS use } \\
\text { (years) }\end{array}$ & $\begin{array}{l}\text { Length of } \\
\text { AAS } \\
\text { withdrawal } \\
\text { (years) }\end{array}$ & $\begin{array}{l}\text { LH } \\
\text { (mlU/ml) }\end{array}$ & $\begin{array}{l}\text { FSH } \\
\text { (mlU/mI) }\end{array}$ & $\begin{array}{l}\text { T } \\
\text { (nmol/I) }\end{array}$ \\
\hline 1 & 22 & 3 & 1.5 & 1.9 & 2.7 & 2.43 \\
8.1 & 6.52 & 7.3 \\
\hline 2 & 31 & 5 & 3 & 2.8 & 3.46 & 2.5 \\
6.7 & 58 & 6.92 \\
\hline 3 & 19 & 3.5 & 1 & $\begin{array}{l}1.1 \\
9.9\end{array}$ & $\begin{array}{l}4.1 \\
6.2\end{array}$ & $\begin{array}{l}1.37 \\
7.12\end{array}$ \\
\hline
\end{tabular}

\begin{tabular}{|l|l|l|l|l|l|l|}
\hline 4 & 24 & 4 & 2.2 & $\begin{array}{l}3.72 \\
9.6\end{array}$ & $\begin{array}{l}3.5 \\
7.46\end{array}$ & $\begin{array}{l}2.91 \\
7.61\end{array}$ \\
\hline 5 & 22 & 5 & 1.2 & 4.1 & $\begin{array}{l}3.53 \\
8.2\end{array}$ & $\begin{array}{l}3.01 \\
9.9\end{array}$ \\
\hline 6 & 28 & 7 & 4 & 4.48 & 3.15 & 2.33 \\
& & & & 7.58 & 4.2 & 7.13 \\
\hline 7 & 27 & 6 & 2 & 1.6 & 2.7 & 3.2 \\
& & & & 9.1 & 7.5 & 8.7 \\
\hline 8 & 30 & 4 & 3.2 & 2.2 & 1.9 & 2.3 \\
& & & & 3.7 & 3.0 & 10.0 \\
\hline 9 & 32 & 4.4 & 2.2 & 2.1 & 0.9 & 1.64 \\
& & & & 11.8 & 3.2 & 6.1 \\
\hline 10 & 29 & 3.0 & 1.5 & 2.68 & 1.8 & 1.61 \\
& & & & 8.7 & 4.1 & 6.56 \\
\hline 11 & 25 & 1.9 & 1.3 & 3.2 & 2.1 & 1.83 \\
& & & & 6.7 & 3.3 & 3.61 \\
\hline 12 & 21 & 2 & 3 & 4.45 & 3.97 & 2.2 \\
& & & & 8.8 & 7.78 & 5.61 \\
\hline 13 & 27 & 2 & 1 & 4.46 & 4.73 & 2.18 \\
& & & & 7.66 & 9.49 & 6.74 \\
\hline
\end{tabular}

Table 1: Raw results of the clomiphene stimulation test in the studied subjects. Hormone concentrations before and after (lines below) administration of clomiphene.

Mean concentrations of $\mathrm{LH}, \mathrm{FSH}$ and $\mathrm{T}$ before and after clomiphene administration were respectively (mean $\pm \mathrm{SD}): 3 \pm 1.2$ and $8.3 \pm 2 \mathrm{mIU} / \mathrm{ml} ; 3 \pm 1.1$ and $10 \pm 14.6 \mathrm{mIU} / \mathrm{ml} ; 2.3 \pm 0.6$ and $7.2 \pm 1.7$ $\mathrm{ng} / \mathrm{ml}(\mathrm{p}<0.001)$ (Table 2).

\begin{tabular}{|c|c|c|c|c|c|c|c|c|}
\hline & \multicolumn{7}{|c|}{ Descriptive statistics } & \multirow{2}{*}{$\begin{array}{l}\text { Wilcox } \\
\text { on } \\
\text { signed- } \\
\text { rank } \\
\text { test } P\end{array}$} \\
\hline & $\begin{array}{l}\text { Mea } \\
\mathrm{n}\end{array}$ & SD & Min & $\begin{array}{l}\text { Lower } \\
\text { Quartile }\end{array}$ & $\begin{array}{l}\text { Media } \\
\mathrm{n}\end{array}$ & $\begin{array}{l}\text { Upper } \\
\text { Quartile }\end{array}$ & Max & \\
\hline \multirow{2}{*}{$\begin{array}{l}\mathrm{LH}(\mathrm{mlU} / \\
\mathrm{ml})\end{array}$} & 2.98 & 1.17 & 1.10 & 2.10 & 2.80 & 4.10 & 4.48 & \multirow[t]{2}{*}{0.0015} \\
\hline & 8.30 & 1.96 & 3.70 & 7.58 & 8.70 & 9.50 & $\begin{array}{l}11.8 \\
0\end{array}$ & \\
\hline \multirow{2}{*}{$\begin{array}{l}\text { FSH(ml } \\
\mathrm{U} / \mathrm{ml})\end{array}$} & 2.96 & 1.08 & 0.90 & 2.10 & 3.15 & 3.53 & 4.73 & \multirow[t]{2}{*}{0.0015} \\
\hline & 9.92 & $\begin{array}{l}14.6 \\
1\end{array}$ & 3.00 & 4.10 & 6.52 & 7.78 & $\begin{array}{l}58.0 \\
0\end{array}$ & \\
\hline \multirow{2}{*}{)$^{T(n g / m l}$} & 2.27 & 0.56 & 1.37 & 1.83 & 2.30 & 2.50 & 3.20 & \multirow[t]{2}{*}{0.0015} \\
\hline & 7.18 & 1.71 & 3.61 & 6.56 & 7.12 & 7.61 & $\begin{array}{l}10.0 \\
0\end{array}$ & \\
\hline
\end{tabular}

Table 2: Changes of hormones concentrations in the clomiphene stimulation test. Hormone concentrations before and after clomiphene citrate (lines below). 
Neither age of athletes, length of AAS use or length of AAS withdrawal influenced the CST outcomes in our study (Table 3).

\begin{tabular}{|c|c|c|c|}
\hline & Age (years) & $\begin{array}{c}\text { Duration of AAS } \\
\text { use(years) }\end{array}$ & $\begin{array}{c}\text { Duration of AAS } \\
\text { withdrawal (years) }\end{array}$ \\
\hline LH & -0.1735 & 0.1215 & -0.3950 \\
\hline FSH & 0.3691 & 0.2928 & 0.0083 \\
\hline T & 0.2121 & 0.1768 & -0.1878 \\
\hline
\end{tabular}

Table 3: Spearman's rank correlation coefficient between: age of subjects, duration of AAS use and duration of withdrawal and changes of concentration of LH, FSH and T.

\section{Discussion}

There is little data on persistent pituitary dysfunction after AAS exposure. Laboratory findings in ASIH usually comprise low/normal levels of gonadotropins and low testosterone. Subjective symptoms do not appear until sometime after the onset of the disorder. Disruption of spermatogenesis may lead to infertility with structural and genetic sperm damage $[17,18]$.

ASIH tends to be temporal. In most cases the androgenic milieu restores within a year after cessation of AAS, however in a number of male athletes low testosterone and sperm production disturbances may persist [19].

ASIH that arises a long time after AAS withdrawal is a poorly recognized condition. The occurrence of ASIH in AAS users is unknown and mechanism leading to hypogonadism and sperm count disturbances remains unexplained. To our knowledge associations between this specific forms of ASIH (eg. duration of AAS abuse, type of AAS used) and alterations of the sperm count have not been addressed in the literature. There is no information on its reversibility as well.

In our experience AAS-induced secondary hypogonadism emerges as an important form of the central nervous system dysfunction. The classical pathways of AAS effects in the brain comprise androgen and estrogen receptors $(\alpha, \beta)$ which are present in highest concentrations in basal telencephalon and diencephalon. Several enzymes play an important role here: $5 \alpha$-reductase, aromatase, $3 \alpha-H S D, 3 \beta-H S D$, and $17 \beta$-HSD. AAS are thought to induce transcription and synthesis of new proteins. They may permanently modify activity of sex steroids receptors [20]. Apart from genomic effects, AAS modulate kinase activity, ion channels, and G-protein second-messenger systems. Some of these actions are much quicker than those induced through transcription factors [20]. Testosterone derivatives may act as partial opioid agonists. They may increase beta-endorphin levels in the ventral tegmental area and the thalamus, decrease levels of kappa receptors in the nucleus accumbens and increase: mu, delta and kappa receptor binding in the hypothalamus, striatum and midbrain periaqueductal gray $[21,22]$. AAS reduce the expression of serotonin receptors in the anterior hypothalamus (1A), globus pallidus (1B) or hippocampus $[23,24]$. They decrease serotonin concentration in basal forebrain and dorsal striatum [25], but increase in the cerebral cortex [26]. AAS are also likely to influence the brain GABA system and modify the mesolimbic dopamine system by stimulation of dopamine release and synthesis [26].
Clinical application of the clomiphene stimulation test (CST) has a long history with well-understood physiological basis [27]. It is a simple and widely accepted tool to evaluate the hypothalamopituitary-gonadal axis in men $[15,16]$. The CST in healthy subjects leads to doubling of $\mathrm{LH}, 20-50 \%$ increase of FSH and $30-220 \%$ increase of testosterone concentration [12]. A similar situation is observed in men with hyperprolactinemia [28] or during aging [29].

In turn organic damage to the CNS or the testicular feminization syndrome are associated with impaired results of the CST [30].

We have to admit that we had no data on the hormonal status of our study cases from before starting AAS doping. However our findings confirm that deregulation of the hypothalamus/the pituitary in men suspected of having ASIH (low LH, FSH and T) is reversible by application of an antiestrogen. Clomiphene stimulation in the studied men induced the same results as in healthy subjects. The mean rise of LH, FSH and T was respectively: $178 \%, 237 \%$ and $215 \%$. Further research is needed to establish the effects of antiestrogens used for longer periods and the influence of this treatment on sperm count. At the moment we have no information on permanence of the antiestrogen effects. There is no doubt that such a pharmacological regimen is more comfortable than gonadotropin therapy. Unlike androgens it has no detrimental effects on gonadal function [31].

We have not observed any differences of gonadotropins or testosterone reactions that would associate with doping course parameters (types of compounds, duration of use, time from withdrawal).

Lack of information on hormonal status (and sperm count) of the investigated subjects before initiation of AAS, missing information on sperm parameters and a small number of cases are major limitations of our observation. All of the studied men declared that clinical symptoms developed after withdrawal of AAS. We can add that five of our cases $(38 \%)$ fathered children. None of them presented clinical features of congenital hypogonadal hypogonadism.

Future research on antiestrogens application in ASIH should involve monitoring of both: hormonal balance and sperm count.

\section{Conclusions}

Long-term AAS users who develop secondary, steroidinduced hypogonadism present an intact reaction of the HPG axis to clomiphene stimulation. Our data support rationale for an antiestrogen application to restore testosterone concentration in such cases.

\section{References}

1. Dunn M, White V (2011) The epidemiology of anabolic-androgenic steroid use among Australian secondary school students. J Sci Med Sport 14: 10-14.

2. Lood Y, Eklund A, Garle M, Ahlner J (2012) Anabolic androgenic steroids in police cases in Sweden 1999-2009. Forensic Sci Int 219: 199-204.

3. Galduróz JC, Noto AR, Nappo SA, Carlini EA (2005) Household survey on drug abuse in Brazil: study involving the 107 major cities of the country--2001. Addict Behav 30: 545-556.

4. Racho̊̊ D, Pokrywka L, Suchecka-Racho ̊, K (2006) Prevalence and risk factors of anabolic-androgenic steroids (AAS) abuse among adolescents and young adults in Poland. Soz Praventivmed 51: 392-398.

5. Harmer PA (2010) Anabolic-androgenic steroid use among young male and female athletes: is the game to blame? Br J Sports Med 44: 26-31. 
Citation: Medras M, Jozkow P, Terpilowski L, Zagocka E (2014) Clomiphene Stimulation Test in Men Abusing Anabolic-Androgenic Steroids for Long Time. J Steroids Hormon Sci 5: 129. doi:10.4172/2157-7536.1000129

Page 4 of 4

6. Kanayama G, Hudson JI, Pope HG Jr (2008) Long-term psychiatric and medical consequences of anabolic-androgenic steroid abuse: a looming public health concern? Drug Alcohol Depend 98: 1-12.

7. Angell P, Chester N, Green D, Somauroo J, Whyte G, et al. (2012) Anabolic steroids and cardiovascular risk. Sports Med 42: 119-134.

8. Turillazzi E, Perilli G, Di Paolo M, Neri M, Riezzo I, et al. (2011) Side effects of AAS abuse: an overview. Mini Rev Med Chem 11:374-389.

9. Quaglio G, Fornasiero A, Mezzelani P, Moreschini S, Lugoboni F, et al. (2009) Anabolic steroids: dependence and complications of chronic use. Intern Emerg Med 4: 289-296.

10. Tan RS, Scally MC (2009) Anabolic steroid-induced hypogonadismtowards a unified hypothesis of anabolic steroid action. Med Hypotheses 72: 723-728.

11. Traish AM, Miner MM, Morgentaler A, Zitzmann M (2011) Testosterone deficiency. Am J Med 124: 578-587.

12. Brower KJ (2009) Anabolic steroid abuse and dependence in clinical practice. Phys Sportsmed 37: 131-140.

13. Salenave S, Trabado S, Maione L, Brailly-Tabard S, Young J (2012) Male acquired hypogonadotropic hypogonadism: diagnosis and treatment. Ann Endocrinol (Paris) 73: 141-146.

14. Kanayama G, Brower KJ, Wood RI, Hudson JI, Pope HG Jr (2010) Treatment of anabolic-androgenic steroid dependence: Emerging evidence and its implications. Drug Alcohol Depend 109: 6-13.

15. Petak SM, Nankin HR, Spark RF, Swerdloff RS, Rodriguez-Rigau LJ (2002) American Association of Clinical Endocrinologists Medica Guidelines for clinical practice for the evaluation and treatment of hypogonadism in adult male patients--2002 update. Endocr Pract 8: 440-456.

16. Rabijewski M, Zgliczẙ̊,ski W (2009) [Pathogenesis, evaluation and treatment of hypogonadism in men]. Endokrynol Pol 60: 222-233.

17. Pope HG, Kanayama G, Ionescu-Pioggia M, Hudson JI (2004) Anabolic steroid users' attitudes towards physicians. Addiction 99: 1189-1194.

18. de Souza GL, Hallak J (2011) Anabolic steroids and male infertility: a comprehensive review. BJU Int 108: 1860-1865.

19. van Breda E, Keizer HA, Kuipers H, Wolffenbuttel BH (2003) Androgenic anabolic steroid use and severe hypothalamic-pituitary dysfunction: a case study. Int J Sports Med 24: 195-196.

20. Wood RI (2008) Anabolic-androgenic steroid dependence? Insights from animals and humans. Front Neuroendocrinol 29: 490-506.
21. Johansson P, Hallberg M, Kindlundh A, Nyberg F (2000) The effect on opioid peptides in the rat brain, after chronic treatment with the anabolic androgenic steroid, nandrolone decanoate. Brain Res Bull 51: 413-418.

22. Johansson P, Lindqvist A, Nyberg F, Fahlke C (2000) Anabolic androgenic steroids affects alcohol intake, defensive behaviors and brain opioid peptides in the rat. Pharmacol Biochem Behav 67: 271-279.

23. Ricci LA, Rasakham K, Grimes JM, Melloni RH, Jr. (2006) Serotonin-1A receptor activity and expression modulate adolescent anabolic/ androgenic steroid-induced aggression in hamsters. Pharmacol Biochem Behav 85: 1-11.

24. Kindlundh AM, Lindblom J, Bergström L, Nyberg F (2003) The anabolicandrogenic steroid nandrolone induces alterations in the density of serotonergic 5HT1B and 5HT2 receptors in the male rat brain. Neuroscience 119: 113-120.

25. Lindqvist AS, Johansson-Steensland P, Nyberg F, Fahlke C (2002) Anabolic androgenic steroid affects competitive behaviour, behavioural response to ethanol and brain serotonin levels. Behav Brain Res 133: 21-29.

26. Kurling S, Kankaanpää A, Ellermaa S, Karila T, Seppälä T (2005) The effect of sub-chronic nandrolone decanoate treatment on dopaminergic and serotonergic neuronal systems in the brains of rats. Brain Res 1044: 67-75.

27. Santen RJ, Leonard JM, Sherins RJ, Gandy HM, Paulsen CA (1971) Short- and long-term effects of clomiphene citrate on the pituitarytesticular axis. J Clin Endocrinol Metab 33: 970-979.

28. Ribeiro RS, Abucham J (2009) Recovery of persistent hypogonadism by clomiphene in males with prolactinomas under dopamine agonist treatment. Eur J Endocrinol 161: 163-169.

29. Da Ros CT, Averbeck MA (2012) Twenty-five milligrams of clomiphene citrate presents positive effect on treatment of male testosterone deficiency - a prospective study. Int Braz J Urol 38: 512-518.

30. Medina M, Ulloa-Aguirre A, Fernández MA, Pérez-Palacios G (1980) The role of oestrogens on gonadotrophin secretion in the testicular feminization syndrome. Acta Endocrinol (Copenh) 95: 314-318.

31. MedraÅ> M, Tworowska U (2001) [Treatment strategies of withdrawal from long-term use of anabolic-androgenic steroids]. Pol Merkur Lekarski 11: 535-538. 